\title{
China's Bilateral Diplomacy in the Arctic
}

\begin{abstract}
This article investigates China's bilateral diplomacy in the Arctic towards the USA, Canada, Denmark/Greenland, Norway, Russia and Iceland. In seeking to identify (1) the most important bilateral issues, (2) whether China's diplomacy towards some of Arctic states has been more successful than others, and (3) the long-term goals of China's Arctic diplomacy and presence, the article utilizes insights from theories of diplomacy in IR as well as the particular historical experiences of the PRC. It concludes with identifying how Beijing's utmost concern when it comes to foreign policy still centers on promoting economic benefits and creating a global presence conducive to economic growth. Yet, while economic factors undoubtedly preoccupy Chinese decision-making in the Arctic, Chinese representatives currently speak less about economic development than about their environmental concerns. Chinese footprints in the Arctic have been adequately established primarily in the scientific research field, while commerce and multi-lateral governance are secondary. Further, it is also apparent that China has been developing contracts with the smaller Arctic powers of Denmark and Iceland (and earlier also attempted to do so with Norway) to facilitate collaborations in both Arctic research as well as economic development. With the bigger Arctic powers, such as the USA and Russia, China appears to prioritize other, more pressing bilateral issues than those pertaining solely to the Arctic.
\end{abstract}

Authors: Jingchao Peng*

Njord Wegge*

*The authors are equally responsible for the article

\section{Introduction}

Diplomacy is a key activity of states in international relations (IR), and can be viewed as a tool that enables states to achieve specific goals. This article investigates China's Arctic diplomacy with a special focus on the People's Republic of China's (PRC) bilateral diplomacy towards the five Arctic Ocean costal states (USA, Canada, Denmark/Greenland, Norway and Russia, or the A5) plus Iceland.

As China's global influence and power are rising, so is its diplomacy also becoming more active. China's Arctic diplomacy is in this respect an interesting empirical case to investigate, as the region is a rather new area of interest to the PRC. The focus on the Arctic is additionally pertinent, as climate change is causing significant changes in the region, especially with respect to diminishing sea ice and increased human activity. The focus on the PRC's bilateral diplomacy is selected as it represents the most important part of China's diplomatic activity in the Arctic, as well as perhaps being the area of the PRC's Arctic diplomacy where systematic academic comparison and scrutiny are lacking.

Specifically, our research questions examine the following: 1) What are the most important driving forces in China's bilateral diplomacy with respect to the A5 plus Iceland? 2) To what 
degree, and why, has China's diplomacy towards some of the Arctic states been more successful than towards others? 3) What are the long term goals of China's Arctic diplomacy and presence?

The six selected Arctic states are chosen as they are the most important ones for China given their size and/or geographic location. Additionally, they represent the states to which China ultimately has been the most active toward. These six states are all also found in proximity to potential future major Arctic shipping routes, and they are of high interest to China with respect to their possession of natural resources, such as petroleum, minerals and fish. These are resources that Chinese actors have important stakes in, either as investors, entrepreneurs or consumers.

The official tone of China's Arctic diplomacy is set by Beijing as one that pursues cooperation and mutual benefits with Arctic states. Liu Zhenmin, former Assistant Minister of Foreign Affairs puts it the following way: "As a non-Arctic state, China is ready to discuss what kind of cooperation should be developed between Arctic and non-Arctic states" (Zhenmin 2011). In China's view, a warmer Arctic gives China both new economic opportunities as well as bringing about new environmental challenges of extreme weather, even to mainland China (Wu et al. 2013). To advance its apparent interests, China has readily engaged in a multi-layered diplomacy in recent years. To date, the result can be concluded as being a limited success. China secured a permanent observer seat in the Arctic Council, the inter-governmental organ that leads multilateral governance in the Arctic. However, at the same time, China's proactive play in the Arctic has raised voices among the Arctic states questioning China's true intentions in the North. Essentially questions have been raised concerning the degree to which China is using its economic clout to promote its unilateral strategic interests, interests that do not necessarily overlap with those of the Arctic states. Taking into account China's global diplomacy, the Arctic states' mixed reaction to the increasing Chinese presence and diplomatic activity hence corresponds to what is found in remote regions outside of China, such as Latin America and Africa.

In the last decade, the Chinese presence in the Arctic has grown. In addition to conducting routine scientific expeditions, China's Arctic diplomacy has increasingly focused on political buildup. Beijing broke a particular important impasse in 2013 when China was granted permanent observer status in the Arctic Council, along with five other non-Arctic states (South Korea, Japan, India, Singapore, and Italy). The decision came only after strenuous debates within the Arctic states, including multiple exchanges between them and the applicants for observer status on the issue over several years (Myers 2013, Wegge 2014: 8990). Along with its diplomatic efforts for a non-Arctic state observer status in the Arctic Council, China has also pursued a parallel track aimed at strengthening its bilateral ties with the Arctic states. Additionally, it has also made remarkable domestic investments to boost its Arctic capacity. Examples of this development include the following: building a second icebreaking research vessel, which is supposed to be operative in 2017; developing and sending a small heavy-lift ship, Yong Sheng (COSCO), through the Northern Sea Route in the summer of 2013, while China's state-owned icebreaking research vessel, Xue Long, has frequented Arctic waters and ports for years (Staalesen 2013). Chinese investors are also reported to have demonstrated great interest in the energy and mineral sectors of the Arctic states, especially in Canada and Greenland. These developments together evoke the image of a state that is in the process of developing its Arctic interests by adopting a broad approach. Even though China's presence in the Arctic makes up only a tiny portion of China's global outreach, it still illustrates a state ready to engage and utilize windows of opportunities when such opportunities mature. 


\section{China's Diplomacy - background and practice}

Diplomacy is an essential part of the Chinese state system, and has its key functions in information gathering, representation, giving policy advice or conducting negotiations and talks with external actors on behalf of the home government (White 2001 326). Diplomacy is closely linked to state power, in embodying a tool to promote a state's interests abroad on a large variety of issues. However, while 'state power' in IR is often associated with a state's capabilities and the threat of the use of force, diplomacy also has a more "civic strain". Hedley Bull writes in his seminal Anarchical society that the diplomat "seeks to always reason or persuade rather than bully or threaten. He tries to show that the objective for which he is seeking is consistent with the other party's interest, as well as his own". Adding to this, in seeking to reach state-goals through agreements rather than through the application of military force, the diplomat "prefers to speak of 'rights' rather than of 'demands', and to show that these rights flow from rules or principles which both states hold in common and which the other state has already conceded" (Bull 1977/1995: 165).

When analyzing the PRC's diplomacy, different approaches can be selected. In several accounts, issues of identity and China's historical experiences are emphasized (Zhu 2013: 16). Such approaches build on the idea that a state's unique historical experiences should be given attention in an analysis (Bjola and Kornprobst 2013: 104-105). Taking into account China's millennium-long dynastic past and its self-image as the "Middle Kingdom" has hence become essential. This is also true of its more recent and modern past where the "century of national humiliation" stands out as a defining period. This century, usually referred to as the period between the Opium War in 1839 until the end of the Sino-Japanese war in 1945, was a period during which China was dominated by several foreign imperialist powers. It has been argued that the suffering felt by the Chinese people during this period still strongly affects the national psyche and identity, particularly of the elite, and it is a sentiment that influences how the elites of the present day relate to foreign states (Wang 2013; Lanteigne 2013 35; Gries 2004). Moreover, while Mao defeated the western-backed Chiang Kai-shek in 1949, the communist regime was not recognized by several western powers, including its Asian neighbors such as Japan, for over two decades until 1972. Nor was the communist government of the PRC acknowledged in the UN as a representative of China before 1971. Mistrust toward the international community and especially the diplomatic system has therefore long been a characteristic feature of the ruling communist party's perceptions of the international diplomatic environment. Only after the end of the Cultural Revolution (19661976) and the introduction of a new area of reform and opening under Deng Xiaoping has China's relationship towards the foreign world gradually become normalized (Liu 2011; Lanteigne 2013).

Approaches focusing on issues of identity, historical experiences and culture tend to move beyond rational inquiries regarding utility and questions on how to solve problems in the most efficient way (Adler 2013). Addressing the role of identity in a state's diplomatic service might hence shed light on different dimensions of that state's interests, including the issue of how interests are generated or constructed (Wendt 1999; Bjola and Kornprobst 2013: 123127). The issues of identity and heritage of the past certainly matter in China's Arctic diplomacy, but including such dimensions in studies tends to go beyond what is verifiable from a "rationalist approach" of the topic, as explanatory factors go beyond rationality and mere calculations of a priori given state interests. The secrecy of the Chinese communist party's affairs additionally makes it hard to understand the thinking of the elites in charge in today's China. Nevertheless, issues of identity and self-image should indeed be included in an 
overall analysis of the Chinese government's actions in order to complement more rationalist, analytical approaches that primarily focus on material factors and utility.

From Deng Xiaoping and on through Jiang Zemin, Hu Jintao and also the current leadership of Xi Jinping, economic growth and a "normalization" of China's external relationship have been core features of the government's priorities. China's entrance into the WTO in 2001 is in this respect one of its most important milestones (Zhu 2013: 7). As Chinese diplomacy can be identified as being driven by a desire to support the Chinese Communist Party (CCP), thereby ensuring the party stays in power, bilateral disputes involving Chinese dissidents or issues that are relevant to the upholding of domestic order are taken very seriously by the political leadership. Recent responses to foreign states engaging in, or commenting on, the democratic protests in Hong Kong during the fall of 2014, or the freezing of bilateral ties with Norway after the Nobel Peace prize was awarded to the Chinese dissident Liu Xiaobo in 2010, illustrate this policy. As the CCP continually seeks to reassert its legitimacy in the absence of elections, this dimension should not be underestimated when analyzing China's diplomatic corps as essentially being an extended body of the party (Shambaugh 2013: 56). Additionally, while the challenge from Chinese dissidents or domestic groups seeking democratic reforms is a key challenge for the Chinese leadership to tackle some relationships are particularly sensitive. As the CCP came to power by overturning the Japanese and Western imperialist powers, thus restoring its dignity and respect, its relationships with Japan and the West are particularly sensitive, as such relationships are directly linked to the work of upholding the legitimacy of the communist party. (Gries 2004; Shambaugh 2013: 56).

It should also be noted that revealing the private calculus used by Chinese leaders when making important foreign policy decisions is a grave crime for Chinese scholars and that severe punishments might be given out (Sutter 2013: 14). Analysts are hence usually left with (vague) analyses based on observations of the behavior of the Chinese government, in combination with more objective variables, such as economic and security interests, as well as the cultural properties and knowledge of the values and identities shared by the elite. Yet interviews with anonymous representatives from the government or ministries might still be suitable to reveal information of a more internal nature.

China's decades-long economic growth stands out as astonishing and impressive to most observers and has few, if any, parallels. With costly arrangements such as the Beijing Summer Olympics in 2008 and World Expo 2010 in Shanghai, in addition to the fact that a growing and more affluent Chinese middle class is now emerging, a new pride and self-image are being experienced among many Chinese. Yet, this new pride, patriotism, and on some occasions, assertiveness are also paralleled with a deeper domestic insecurity among the political leaders on behalf of the regime (Shambaugh 2013: 54, 58-59). As a state's diplomacy is closely connected to the governing elite and the political leadership, the ideological beliefs and fears of the political leaders are indeed likely to influence the diplomacy of a country like China.

David Shambaugh, Professor at George Washington University and longtime resident of Beijing, describes China's multifaceted rise as "the big story of our era" (Shambaugh 2013: ix). However, according to Shambaugh, despite its economic, military and technological rise, China remains a "partial power", arguing that its global power is surprisingly weak and very uneven (Shambaugh 2013). While China has an increasingly broad footprint across the globe, its impact is not particularly deep, and its appeal as a "model" to other states is generally weak or non-existent. (Shambaugh 2013: 6-7). A somewhat similar picture can also be found 
with respect to the PRC's diplomacy; despite its global presence and integration into the international community, China remains remarkably reactive and passive despite initiatives in specific areas, such as its leading role in the UN's G77 (Shambaugh 2013: 6-7). The relatively passive role of China on issues of global politics has been identified in fora such as the G-20, as well as in most forums in the UN (Chin 2013: 890). The PRC's voting behavior in important institutions such as the UN Security Council (UNSC) illustrates this, where China as a nominally very powerful state generally appears as passive, rarely taking the lead, e.g., through serving as a pen-holder or an initiator of new policy. This rather reactive and passive role might stem from a strong belief in non-interference and distrust toward westerndominated institutions. ${ }^{1}$

While the PRC may be perceived as hesitant to play a leading role in multilateral fora, its bilateral-diplomacy is often found to be more active, particularly with respect to promoting its national economic interests (Shambaugh 2013: 55). The Chinese "resource-diplomacy", which is particularly associated with recent Chinese investment offensives in Latin America and Africa, is hence also an interesting parallel when analyzing Chinese interest and presence in the Arctic (Zhu 2013: 21-51, 81-112; Taylor 2007; Carmody and Taylor 2010).

With a transition from the 'revolutionary diplomacy' seen under Mao to the more 'pragmatic diplomacy' developed under Deng Xiaoping, peace and economic development have been at the core (Liu 2011: 120). In this respect, it has been argued that "China's diplomacy went global because China's commerce had gone global” (Shambaugh 2013: 55).

It should also be noted that China's "resource diplomacy" stands out as being rather transparent, in contradiction to other parts of its diplomacy. This openness might partly be a consequence of its WTO membership, which imposes certain standards on member states, but might also be caused by the large number of Chinese actors involved. In this context, the strategy of giving priority to commercial partnerships abroad often implies visits by key trading partners, and an openness with respect to signing contracts.

In the Arctic, the drive for resources and commercial opportunities stands out as important, and at the same time, the term Science Diplomacy might be even more fitting, as subsequent sections of this article will elaborate. While the potential for Chinese utilization of resources in the Arctic is important, and the promise of commercial shipping opportunities is relative high on the agenda, scientific activities probably remain the most important dimension of Chinese engagement in the Arctic today.

\section{Conceptualizing China's Arctic Diplomacy}

The findings in this article suggest that China's desire to advance both its strategic interests and its trade interests has driven its diplomacy in the Arctic. However, what is less clear, and perhaps more important, is how China's diplomacy is formulated, directed and re-defined within the Chinese government, and what kind of diplomatic outcome it aspires to.

\footnotetext{
${ }^{1}$ Over time, the so-called Five Principles of Peaceful Coexistence have come to represent the most important guiding principles of the PRC's foreign policy. The principles were established as the foreign policy guidelines of the 1950 s and sum up to: 1) Mutual respect for each other's territorial integrity and sovereignty; 2) Mutual non-aggression; 3) Mutual non-interference in each other's internal affairs; 4) Equality and cooperation for mutual benefit and; 5) Peaceful coexistence (Zhu 2013: 14-15).
} 
Based on empirical evidence, China's foray into the Arctic does not appear to lend support to the idea that purely materialistic pursuits determine the shape of its bilateral diplomacy. In the past few years, Beijing's bilateral relationship with the Arctic states has clearly shown that self-image, ideology, and geopolitical posture are no less important for Beijing in bilateral diplomacy than economic interests. However, there are two caveats concerning the non-economic factors driving China's bilateral diplomacy. First, there is a lack of information for researchers to underpin the policy sphere of China's Arctic venture. The Chinese government released no more than a few moderate statements on Arctic affairs. Beijing is clearly trying to maintain a low-key profile in the Arctic region, and under a political system like China's, this means that businesses and academia must not go against such a profile. Second, there is also a blurry issue with regard to China's decision-making process in diplomacy. It appears that the more pressing the issue involving 'national interests' in China is, the more centralized the decision-making process on that issue appears to be. In this case, the Arctic remains an unfamiliar frontier that China's policy-makers have yet to comprehend substantially. So far there is no solid proof to suggest that Beijing has a master plan for its Arctic interests. In fact, it seems more likely that Beijing is going through a process of assessment and research on what the Arctic implies for China as a growing world power.

The following section attempts to present a brief overview of engagements between Beijing and key Arctic states on Arctic subjects, with a special focus on Chinese perspectives and thought. Our purpose in examining China's Arctic footprints in bilateral diplomacy is also to partly compare them with China's past ventures into foreign areas that were also remote and unfamiliar, but attracted Chinese interests with their vast economic potential (such as Africa and Latin America). This will help us to better understand what the Arctic's transforming geopolitical and economic landscape is likely to imply for China. It will also help us to better predict what policy trajectory China is likely to develop in the future on Arctic issues.

\section{Sino-Russian Arctic Relations}

In having the largest Arctic territory, EEZ and continental shelf, Russia is jockeying for a leading role in Arctic governance. This is manifested in a statement by Russia's President, Vladimir Putin that '....we must take additional measures not to fall behind our partners, to keep our influence in the region and in some aspects be ahead of our partners' (Reuters 2014). To achieve such an ambition, the 2013 Russian Strategy of the Development of the Arctic Zone and the Provision of National Security until 2020 attaches great importance to the development of energy bases, infrastructure and a Northen Sea Route in the Arctic territory (Aspen Institute 2014).

For Chinese policy-makers and investors, Russia's energy potential in the Arctic provides the perfect condition for a Sino-Russian oil partnership. Cooperation on oil matters has apparently been the central area of focus in current Sino-Russian Arctic relations. At the moment, other forms of cooperation, such as those in the sciences or on the social frontier remained unseen. Early in 2014, Sinopec and Novatek signed an agreement in which Sinopec gained 20\% of the shares in Novatek's LNG extraction and export dealings in the Yamal region (China Economic Times 2015). The China National Petroleum Corporation (CNPC) and Sovcomflot Group signed an initial agreement concerning the shipment of hydrocarbons along the Northern Sea Route (Voice of Russia 2014). At the Asia Security Forum in Shanghai in May of 2014, Russia and China signed a joint agreement (in addition to the 
ground-breaking $\$ 400$ billion natural gas deal), by which the Kremlin vowed to provide Chinese ships with logistic assistance for navigation through the Northern Sea Route (Barents Observer 2014).

It is worth noting that none of these new deals have thus far materialized on the ground. Nor were they able to temper Russia's highly skeptical attitude towards opening its Arctic resources to non-Arctic states (Global Times 2013). The two postponements of permanent observer decisions were reportedly due to objections by both Russia and Canada. Russia's ambivalence on this matter set off palpable distrust and uncertainty among Chinese Arctic observers, who publicly spoke about Moscow's ambition to 'carve most of the Arctic for its own' (Kuang 2011), hinting that the Russian regulations over the Northern Sea Route are not in compliance with the UNCLOS (Zhang et al. 2013).

However, as the Crimean crisis gradually played out and Russia's economy continues to be weakened by Western sanctions, Sino-Russian relations on the Arctic may accelerate. The meeting between Chinese Vice Premier Zhang Gaoli and Russian Deputy Prime Minister, Igor Shuvalov in St. Petersburg, Russia on June 18, 2015 is a good illustration of this new tendency, leading the China-Russia Investment Cooperation Committee into a more practical forum (CCTV 2015). Obviously, such cooperation carries a great deal of political ramifications. By forming an "alliance", the Kremlin and Beijing can go a long way in maneuvering the power balance in Eurasia, and in checking so-called "hostility from western liberal democracies', who control important parts of the world's energy hubs. For the security of energy supplies, Russia's hydrocarbon reserves are critical for aiding Beijing's import diversification strategy. Diversification is considered to be an imperative task by the Chinese government to reduce its great dependence on the Strait of Malacca for transporting oil (He and Zhao 2013). At the same time, Russia needs to revitalize its stagnant output by tapping into the underdeveloped Asian markets, especially given the current situation where its longterm European consumers have been shifting their energy dependence away from Russia, following the Ukraine crisis.

Against this backdrop, China's Arctic diplomacy with Russia has been portrayed as one that 'treads the water very carefully' (China Economic Weekly 2013). One the one hand, China stands ready to cooperate with Russia, in anticipating Chinese investments in exchange for Moscow's political support. One the other hand, China remains circumspect toward the diplomacy outcome with Russia and stands ready to mobilize its diplomatic resources elsewhere in order to pursue its Arctic interests. Such a policy stance is consistent with one of China's traditional foreign policy doctrines, that is, to prioritize economic development over strategic maneuvering. According to this way of thinking, China is motivated to stay pragmatic and cautious. While the prospect of cooperating with Russia appears to be lucrative business and also beneficial to its strategic interests, past empirical experiences have proven to Chinese policymakers and businessmen that cooperating with Russia based on their strategic assets is always strenuous and risky (Holtm et al. 2011). However, China's hunger for an ally in the areas of energy and politics in the Arctic may force Beijing to accept the role of as junior partner in this key bilateral relationship in the region (Sun 2014). Similarly, an enhanced focus on scientific research and climate change, as well as an investigation into how changes in Arctic ice extent might impact the weather in mainland China has also diminished the focus on potential economic gains in collaborating with Russia.

With respect to the shipping opportunities through the NSR one should also note that the "promise' of future Arctic trade routes has often misunderstood by Chinese diplomats, leaders and even shipping executives. While the potential of the NSR, when comparing the distance from China to Europe with the Suez Chanel, might seem great, the new Arctic routes are understood by most experts to be seasonal at best. Similarly are few experts 
suggesting that the Arctic routes will revolutionize the open ocean global trade routes of today, an impression the "media hype" sometimes might leave.

\section{Sino-Canadian Arctic relations}

Compared to Russia, China's Arctic cooperation with Canada carries less geopolitical significance. At the moment, Sino-Canadian cooperation in the Arctic is highly hinged on economic and commercial developments, while scientific cooperation also might be on the rise. China is in this respect trying to mix science and research with business interests. Beijing is reported to be looking to set up a research outpost in northern Canada to support studies on the Northern Sea Route and future energy development (The Globe and Mail 2015).

China considers Canada a key exporter of energy and mineral products. The latest statistics from China's Ministry of Commerce shows that nearly 25 percent of Canadian exports to China are from the energy and mineral sectors (Ministry of Commerce, PRC 2013). Between 2007 and 2013, the major Chinese state-owned oil firms, China Petroleum \& Chemical Corporation (Sinopec) and China National Offshore Oil Corporation (CNOOC) have poured more than 119 billion US dollars into Canadian energy sectors (Daly 2014). In terms of shipping, it looks like China has not prioritized the Northwest Passage as part of the Arctic agenda with Canada. Some scholars have argued that the Northwest Passage does not yet offer the best conditions for commercial usage, and this is partly because of Canada's strict environmental regulations (Bai and Li 2014).

In September 2012, a Foreign Investment Promotion and Protection Agreement between China and Canada was signed, and following that agreement, Beijing and Ottawa were reported to be working towards a free trade agreement (The Star 2012). The investment enthusiasm on the part of the Chinese is unlikely to diminish anytime soon. However, China's growing presence in Canada has already raised local concerns, especially with regard to the murky linkage between the government and businesses. In a nutshell, Canadians are concerned that accepting Chinese investments comes with a high cost (Lajeunesse and Lackenbauer 2013) Will Canada's open policy toward Chinese capital lead to Canada diminishing its control over its natural resources to the benefit of the Chinese state-owned enterprises in the long term (Heubert 2012). Another layer of fear attached to these Chinese state-owned enterprises is that they are tools or puppets of the government, which it can exploit for its own geoplitical interests when necessary (Wright 2013). This is a particularly sensitive issue in Canada's large Arctic territories, which are sparsely populated.

\section{Sino-US Arctic relations}

The Arctic issue remains a marginal one in the overall complex of Sino-US relations. The United States undoubtedly retains a central role in the changing foreign policy calculations of Beijing (Sutter 2013). Yet when it comes to the Arctic, the bilateral relationship to the US has not played a major role in China's Arctic diplomacy. Nor does China consider United States a key partner to promoting Chinese interests. One explanation could be that Chinese policymakers do not consider the US an opponent to China's Arctic interests. Nevertheless, since the US has taken over as chairman of the Arctic Council as of April 2015, renewed interest has been put on the US's role in Arctic governance, promoting science and international research in the region. Yet, as both the publication of the US National Strategy for the Arctic Region in May 2013, as well as the Executive Order: Enhancing Coordination of National Efforts in the Arctic from January 21, 2015 declare that Washington will seek to work with other states and entities to advance common objectives in 
the Arctic region (White House 2015), China may have felt it has little to fear from the US in its campaign to enhance its Arctic presence and relevance. Still, there could also be other explanations for the apparent lack of specifically Sino-US diplomatic exchanges on Arctic issues. As Arctic issues are largely overshadowed by other more pressing topics in bilateral negotiations, such as trade frictions, China's increasing maritime assertiveness and opaque military buildup, and increasingly strong-willed military posturing in the Asia-Pacific, Arctic issues might have been shuffled down the mutual priority list of the two great powers (The Diplomat 2015; Peng and Wegge 2014).

The Arctic has been included in the annual US-Sino Strategic and Economic Dialogue since 2011, but it has appeared as a topic that merely deserved an exchange of opinions (US Department of State, 2013; Sun 2014). The United States is naturally an Arctic state due to the state of Alaska being situated partly to the north of the Arctic Circle. Concerning the Arctic waterways, the United States holds that freedom of navigation should be applied according to the law of the Sea, which is understood as customary international law, as the US is not a party to the UNCLOS. According to the Law of the Sea Convention, freedom of passage in Exclusive Economic Zones and high seas should be granted to ships of all nations. The 2013 White House National Strategy for the Arctic Region also announces that the United States 'has a national interest in preserving all of the rights, freedoms, and uses of the sea and airspace recognized under international law' (White House 2013). Yet even with regard to these apparently favorable policy principles, Chinese officials and Arctic specialists remain reluctant to respond. Beijing's reluctance to engage more positively with the United States in the Arctic seems to reflect the Chinese leadership's deep-rooted suspicion of American ocean domination. Such caution is even more palpable among academics. Hence, it may not be advisable for China to express too much support for the US on this point, as in doing so it might risk alienating Russia and thus potentially undermine the Sino-Russian relationship (Li 2014). Further, If China were to publicly embrace the American concept of 'freedom of navigation', this might put more pressure on China to relax its more restrictive 'freedom of navigation' policies that it has imposed on China's home seas. In this respect, China might have to confront the fact that its assertion of rights in utilizing Arctic shipping routes is inconsistent with Beijing's marine policies in its regional waters. Yet, Sino-U.S. Arctic relations may improve during the ongoing U.S. Arctic Council Chairmanship; in May 15-17, 2015 the first China-U.S. Arctic Policy Workshop was held in Shanghai (among academics and government ministerial experts at Tongji University). Annual meetings are also planned with the next in Washington, D.C. in April/May 2016. In sum, China's Arctic diplomacy with the United States contains an unspoken impasse. Although the United States maintains a positive attitude towards Chinese participation in Arctic affairs, Beijing would be reluctant to engage further with the United States in order to prevent itself from becoming the target of debate whenever the concept of 'freedom of navigation' is evoked in Arctic governance.

\section{Sino-Icelandic Arctic Relations}

The extent and intensity of China's Arctic diplomacy are prominently displayed through its relationships with the Nordic countries. These are bilateral relationships where both successes as well as major challenges for the PRC can be seen. Overall, China's romance with its Nordic counterparts involves cultivating a sense of mutual benefits, evoking an image as a 'student of Arctic expertise' where China can also contribute to the common good of the region (Robinson 2013).

Of all the Arctic states, Iceland has turned out to be the most enthusiastic country to embark on an extensive Arctic partnership with China. After Reykjavik's economy went 
through a slump in 2008, Chinese investors quickly saw this as an opportunity and made their way into the Icelandic economy. In 2010, China engaged in a 500 million USD currency swap deal (Barents Observer 2011). In April 2012, former Premier Wen Jiabao visited Iceland and signed a number of bilateral deals, including a framework accord on Arctic cooperation (Rainwater 2013). During the bilateral-meetings, Iceland eagerly offered China support for its permanent observer application on the Arctic Council. In early 2014, the China National Offshore Oil Company (CNOOC) paired with Iceland's Eykon Energy and acquired an exploration license in the sea area south of Jan Mayen Island. In addition, Beijing left a remarkable footprint on Iceland's landscape with a brand new embassy, a joint Arctic research center, - fully financed by the Chinese - and in demonstrating its intention to invest in new port facilities. Iceland reciprocated with offering political support for an expanded Chinese role as an actor in the Arctic. It is reasonable to assume that China clearly anticipates Iceland to play a key role in its future as a shipping hub, and as a logistical center for China's Arctic activities, including scientific reseach, e.g., on the aurora borealis and climate change. Chinese involvement might also include the development of infrastructure that can support Chinese mineral activities in East-Greenland, given its proximity to northwest Iceland and the lack of infrastructure found on the East Greenlandic coast (Lanteigne 2014: 16).

China did also establish "The China-Nordic Research Center (CNARC), in Shanghai, 10th December 2013, between four Chinese and six Nordic research institutions (CNARC 2013: 2). In this cooperation Iceland has gotten an important bridge-builder role to play, even though the country certainly is the smallest country among the Nordic family.

Symptomatically Iceland was selected to host the second CNARC-conference in Akureyri in the spring of 2014. The CNARC cooperation is also a good illustration of the importance the Chinese government give to the Nordic states in the Arctic, not the least with respect to stimulate to the development of multilateral cooperation between Chinese and Nordic institutions within the natural sciences.

\section{China's Arctic Relations with Denmark and Greenland}

Greenland represents in many ways a showcase of China's 'resource diplomacy'. Flush with capital, China has been eyeing Greenland's abundant mineral resources with eagerness. In 2011, Sichuan Xinye Mining Investment Co, a state-owned firm, was reported to have inked a deal with London Mining Inc., which owns exploration rights over Greenland's Isua Iron ore mine. Also in 2011, a subsidiary of China Nonferrous Metal Mining Group, Foreign Engineering and Construction Co., signed a non-binding agreement with Australian miner Ironbark Zink to extract zinc near Greenland's Citronen Fjord field. Both projects are in a stalemate after receiving media exposure, and the Chinese strategy since has been to adopt a "wait and see" attitude, not aggressively push forward with controversial projects. Chinese experts are also sensitive to declining global mineral prices and credit conditions, as well as uncertainty over Greenland's employment and environmental regulations. These are all factors stalling its development ( $\mathrm{Pu} 2013)$. However, the business dynamics between Chinese firms and the Greenlandic Ministry of Industry \& Mineral Resources remain strong and Greenlandic officials frequent China to discuss business possibilities (Pu 2013; McGwin 2014). In turn, China commends these welcoming attitudes and often honors its relationships in Greenland with prospects of attractive business deals. In a nutshell, it appears as if the Chinese government has sought to win political support from the Greenlandic government in a quiet fashion, using its economic power, patience and long-term perspective as major leverage. A deliberately enhanced focus on scientific research, instead of purely economic gain, might also soften the natives' attitudes towards increased Chinese engagement. Finally, China has learned to adopt a mild tone even when some deals get stuck and waits patiently for 
new opportunities to break the ice. It is likely that Beijing is content with employing such a mixed strategy in the foreseeable future, which helps China take part in the economic development of the region and maintain a presence there (Perry and Anderson 2014).

A number of joint research projects in the Arctic have in this respect been set up between Denmark and China. Their main focus is on natural science topics, including Arctic geology. Such a model of collaboration is in a good position to extend into other areas. China cozied up to Denmark after its diplomatic fallout with Norway, and because of this cordial relationship, strengthened Denmark's Arctic profile in the region as well. However, interestingly enough, neither the Danish media nor commentators in general have explored how the booming ties between China and Denmark in the Arctic have partly been the result of China's diplomatic freeze with Norway, instead of an originally intended broader Chinese Arctic strategy.

\section{Sino-Norwegian Arctic Relations}

In rhetoric, Beijing claims itself to be a peaceful and cooperative partner in Arctic affairs. However, Norway's diplomatic discourse with China in the past few years is a reminder of the Chinese political leadership's ability and willingness to play hardball when what it perceives as its core interests are threatened. The relationship hit a low in 2010 when China halted all political exchanges to punish Norway for awarding the Nobel Peace Prize to an imprisoned Chinese human rights activist, Liu Xiaobo. These sanctions are ongoing and might in several respects be as strict as ever given Norway's continued refusal to apologize for the awarding of the price. According to media reports, secret attempts to negotiate a deal on behalf of the Norwegian government have also not been successful, particularly as the previous Norwegian Prime Minister, Jens Stoltenberg, did not consent to offering even a secret apology to the Chinese rulers (Dagens Næringsliv 2014; VG 2014). The Liu Xiaobo incident offers a glimpse into China's punitive countenance in foreign policy. When countries offend China with acts interpreted as an intention to meddle with its 'internal affairs', the Chinese government does not hesitate to respond with punitive measures, mainly in the form of cutting off economic and political exchanges (Wegge 2014).

Prior to the Nobel Prize in 2010, Norway was probably the PRC's preferred Arctic partner among the Nordic countries. With its offshore petroleum technology, large/vast natural resources and favorable geography, China had actively strengthened its bilateral ties with Norway. Through establishing formal Chinese-Norwegian dialogue meetings in June 2009, climate change and polar research were particularly identified as issues where the strongest common interests existed (Jakobson 2010: 11). The Chinese establishment of a new research station a few years earlier in Ny-Ålesund, Svalbard, which was facilitated by the Norwegian government, adds to this picture.

As Chinese-Norwegian negotiations on a free trade agreement had almost been concluded by the time of the Nobel award, China would probably have signed the free trade agreement with Norway several years ago, had it not been for the peace price. After the incident, both sides appeared willing to repair the strained political ties but made little headway. Norway's active support of China to become a permanent observer of the Arctic Council should in this respect be noted. Yet, even though Chinese diplomats have asserted the need to rebuild the ruined political trust between the two nations through 'joint efforts', they have made it clear that reconciliation should be based on a Norwegian apology with a guarantee that a similar incident will not take place again in the future. This is not a condition the Norwegian government can accept, thus no viable solution seems to exist mid- 2015 to end the political impasse.

When assessing the impact of this frozen bilateral relationship on practical cooperation in Arctic affairs, most research cooperation, e.g., in Svalbard, or between national research 
agencies, seems to continue more or less unaffected. Similarly, many aspects of bilateral Sino-Norwegian trade have also continued to rise exemplified by how Norwegian salmon exports quickly picked up in 2012. Overall trade has risen sharply since 2011. Yet Chinese researchers seeking to cooperate with Norwegian counterparts have to maintain a more quiet approach at home, as research leaves at Norwegian institutions or conferences today are much harder to obtain from the "political personnel" safeguarding the PRC's political policies at most prominent Chinese universities and research institutions today. ${ }^{2}$ Finally, while Chinese research in Svalbard has particularly involved uncontroversial scientific research on Arctic marine issues, atmospheric phenomena such as the aurora borealis or cryosphere research, recent planned expansions have been declined by the Norwegian government (NRK 2014).

\section{Conclusion}

Despite the increasing complexity, depth and uncertainty of foreign engagements involving China, Beijing's utmost concern when it comes to foreign policy still centers on promoting economic benefits and creating a foreign environment conducive to economic growth. For the Chinese leadership, such a policy is based on two key ideas. First of all, it supports Beijing in sustaining economic growth, and one that closely hinges on international trade and capital investment. This, by and large, determine the ruling CCP's domestic popularity, legitimacy and essentially its existence and survival. Secondly, the power of economic benefits, or the threat of removing such benefits, has proven to be Beijing's mostfavored policy instrument, providing leverage against foreign criticism. Additionally, the foreign policy emphasis on economic development can be interpreted as being related to the leadership's historical distrust toward international diplomacy and multilateralism, as well China's weak tradition of political leadership on the political world stage.

As Chinese leadership has facilitated economic growth through stimulating production, increasing industrial capacity and promoting foreign exports, a greater need for raw materials and new bilateral trade arrangements has also emerged. The PRC's economic logic has in this respect proved to be a key dimension to understanding its diplomatic priority areas. The Chinese leaders' focus on economic growth hence explains why China's bilateral diplomacy tends to be much stronger and more developed than its multilateral diplomatic missions. Chinese diplomacy is therefore generally identified as being mostly concerned with protecting China's economic interests, rather than providing leadership and bringing other states together, or developing new ideas and initiatives (Liu 2011: 121; Shambaugh 2013: 46).

Regime survival should hence been viewed as an important defining feature of China's foreign policy, a strategy that has traditionally included acceptance for a liberal US-dominated world order, even though issues of national sovereignty and regional security interests increasingly have become particularly sensitive to Chinese leaders. Similarly, a diminished focus on communism has gradually been replaced by a greater emphasis on the promotion of patriotism and nationalism (Sutter 2012).

Yet while economic factors undoubtedly preoccupy Chinese decision-making in the Arctic, the political leadership of or Chinese representatives in the Arctic currently speak less to economic development than their environmental concerns. Chinese footprints in the Arctic are adequately established primarily in the field of scientific research, while commerce and multi-lateral governance in the Arctic come afterwards. With the smaller Arctic powers (Denmark and Iceland), Beijing is developing (or, in the case of Norway, - has been

\footnotetext{
${ }^{2}$ Authors personal Communications with 1. Chinese Law of the Sea Scholar and 2. Political Science scholars, on research visit to Norway. Bergen 26. June 2014 and Oslo 27. October 2014.
} 
attempting to develop) contracts to facilitate collaboration in both Arctic research as well as economic development. With the bigger Arctic powers (the US, Russia and also Canada), China appears to prioritize other, more pressing bilateral issues than issues pertaining solely to the Arctic. In short, even though it would be naive not to assume that economic benefits have driven China to watch Arctic more closely, Beijing has been acting with patience in terms of promoting its Arctic interests. It appears willing to take a shot at every investment opportunity, but at the same time does not make it an imperative task. Looking ahead, however, one should question Beijing's long-term strategic objective in the Arctic. As China gradually turns into a global economic and political power, what broader role will the Arctic play for China's international status? In the 30 years that have passed since China opened itself up to the outside world, it has reached out to distant territories to expand its economic and political influence. Prior to 1979, Africa was to China no more than a continent where China could mobilize 'the third world's' political support for its struggle against 'western imperialism'. Now China has already surpassed the United States as Africa's biggest trading partner. The same story could be told about the Sino-Latin American relationship.

In sum, certain patterns can be identified in the way the Chinese government tends to advance its interests overseas, which also includes its Arctic diplomacy. These patterns are associated with China's self-image and identity, distrust of foreign diplomacy, focus on growth and appetite for energy resources. However, Beijing's opaque decision-making process and its cautious official tone make it difficult to predict the true nature of its strategy. How important is, for example, the current Chinese focus on scientific research and environmental issues compared to its long-term economic interests? Can assessments of China's intentions in the Arctic go beyond a mere interpretation of official discourses and foreign policy actions? Current literature and existing research do not in this respect provide sufficient material to make a qualified assessment of the future. Yet it could be argued that the main tendencies characterizing China's current foreign diplomacy are most likely to be continued and that there is also no evidence that China is overhauling or substantially changing its foreign diplomacy in the Arctic region. At the same time, a key question is whether the motivating factors and corresponding Chinese tactics will produce the same favorable outcome in the Arctic as they have in Africa or Latin America in the long run?

When seeking to answer this question, some key observations should be addressed. First, China has an instinctive fear of big power dominance in the Arctic by Russia, the United States, and, to some degree, Canada. At the same time, it has not found a good argument to persuade smaller Arctic states into believing that they actually need China to prevent such dominance in the Arctic. Since its socialist era, China has had a tradition of nurturing ties with remote regions that could help in its efforts to throw off capitalist influence, especially against the US and its western allies. China usually courts such regions by patronizing governments that are hostile to western powers. We can see such recurrent patterns in China's engagements with states in Africa, Latin America, and Middle East. However, the tactic of invoking sentiments of victimhood and seeking leverage against the 'big powers' would not work for Beijing in the Arctic. With the exception of Russia, the Arctic states are all developed liberal democracies who agreed among themselves on a peaceful approach toward Arctic governance, based on the fact that most of the Arctic region is located on their territories, or within the EEZ of the eight Arctic states. This means that there is no natural incentive to collaborate with China for balance-of-power reasons.

Second, the prospect of a robust 'energy diplomacy' is also unlikely to bode well for China in the Arctic. Rising domestic consumption is driving Chinese companies to invest in energy sectors overseas. Some analyses tend to believe that energy security is what is really underwriting Chinese interests in the Arctic ( $\mathrm{Li}$ and Bertelsen 2013). A high dependence on oil shipments through the Strait of Malacca has indeed propelled the Chinese government to 
secure supply contracts that can bypass the Malacca chokepoint. However, many things have must be overcome before Arctic resources could generate a stable supply to China, even from Russia. In this regard, Chinese energy interests in the region occasionally appear to be interests on paper only. The Chinese venture also lack drilling technology and expertise in cold and frozen environments, and there is seemingly no compelling reason for the Arctic countries to formulate joint-ventures with China to explore Arctic resources in the short run, since Chinese investors do not appear to be ready, nor is their technology mature.

China's economic interests in the Arctic are indeed a perplexing issue to analyze. On the one hand, Beijing's official course of action in the Arctic appears to concentrate on scientific research, but at the same time, there is a clear domestic calling from both academia and industry insiders to the Arctic's economic potential. The reality, however, is that the economic potential in the Arctic is mostly found on the territories of the eight Arctic states. This dichotomy between official interlocutors and general public engagement invites the question as to whether the agendas of science and climate research are just a steppingstone or an end point for Beijing's Arctic endeavors. China's future policy could indeed go both ways. It could start to exert influence on Arctic governance on behalf of non-Arctic powers by applying economic pressure - negotiating business and trade deals with Arctic powers to lock them into more economic interdependence. Alternatively, it can continue its current lowprofile policy, which generally avoids attention, disputes and conflicts with Arctic governments and their local populations. Having crossed the basic governance threshold and established a decent research presence, China's next step in the Arctic will serve as an important example for how China might be expected to approach new regions in the world, essentially embodying China's rising power through its diplomatic craft.

\section{References}

ADLER, E., 2013: “Constructivism in International Relations: Sources, Contributions, and debates”. In CARLSNAES, W. et.al. (eds.), Handbook of International Relations. Second Edition. Los Angeles: Sage.

ASPEN INSTITUTE, 2009, Russian Arctic Strategy Until 2020', 24 Mar. 2009. Available at: http://www.aspeninstitute.org/sites/default/files/content/upload/29\%20Russian\%20Arctic\%20Strategy\%20Until $\% 202020 \% 20 \mathrm{BW} . \mathrm{pdf}$

BAI, J., and LI, X., 2014, 俄罗斯和加拿大北极航道法律规制述评一兼论我国北极航线的选择[Northern Sea Routes regulations in Russia and Canada and China's options], Zhongguo Haiyang Daxue Xuebao Shehuikexueban, 2014(6), p. 8.

BARENTS OBSERVER, 2014, China to get better terms on Northern Sea Route, Available at: http://barentsobserver.com/en/arctic/2014/05/china-get-better-terms-northern-sea-route-21-05

BARENTS OBSERVER, 2011, Does China seek Arctic foothold at Iceland?. Available at: http://barentsobserver.com/en/security/does-china-seek-arctic-foothold-iceland.

BJOLA, C., and KORNPROBST M., 2013, Understanding international diplomacy. Theory, practice and ethics. London: Taylor \& Francis Group.

BULL, H., 1977/1995, The Anarchical Society. New York: Palgrave Macmillan.

CARMODY, P., and Taylor, I., 2010, Flexigemony and Force in China's Resource Diplomacy in Africa: Sudan and Zambia Compared". Geopolitics, 15(3): 496-515.

CCTV (2015): China, Russia agree to deepen cooperation in investment. Available at: http://english.cntv.cn/2015/06/20/ARTI1434770289180533.shtml

CNARC, 2013, China-Nordic Arctic Research Center. Newsletter, First Edition, December 2013.

CHINA ECONOMIC TIMES, 2015, 北极圈天然气之星：中俄能源合作开启新篇章 [A New Chapter in SinoRussian Energy Cooperation], Available at: http://www.cet.com.cn/nypd/trq/1567041.shtml 
CHINA ECONOMIC WEEKLY, 2013, 开发北极成本高一定要谨慎 [China must stay alert to the high cost of exploration the Arctic], Available at: http://paper.people.com.cn/zgjizk/html/2013-

05/27/content_1248042.htm?div=-1

CHIN, G., 2013, The economic diplomacy of the rising powers. In COOMER, A.F., et al. (eds.), The Oxford Handbook of Modern Diplomacy. Oxford: Oxford University Press.

DAGENS NÆRINGSLIV, 2014, Stanset hemmelig Kina-løsning. [stopped secret China solution]01. Sept. Available at: http://www.dn.no/nyheter/politikkSamfunn/2014/09/01/2158/Kina/stanset-hemmelig-kinalsning

DALY, C. K., 2014, China's penetration of the Canadian energy market, China Brief, 24, April, 2014, Available at:

http://www.jamestown.org/programs/chinabrief/single/?tx ttnews\%5Btt_news\%5D=42259\&tx ttnews\%5Bback Pid\%5D=25\&cHash=e075194d0986f024753c16668bf2aaab\#.U34AQ1iSxmc

THE DIPLOMAT, 2015, China Is Playing Offense, Not Defense, in the South China Sea. June 04. Available at: http://thediplomat.com/2015/06/china-is-playing-offense-not-defense-in-the-south-china-sea/

GLOBAL TIMES, 2013, Canada, Russia hold key to China's Arctic access, Available at: http://gbtimes.com/world/canada-russia-hold-key-chinas-arctic-access

GRIES, P.H., 2004, China's New Nationalism: Pride, Politics, and Diplomacy. Berkeley: University of California Press.

MCGWIN, K., 2014, China's Arctic allies, The Arctic Journal, 19. Feb. 2014, Available at: http://arcticjournal.com/oil-minerals/433/chinas-arctic-allies.

HE, Y., and ZHAO, Y., 2013, 中俄北极能源合作战略分析 [An analysis of Sino-Russian cooperation strategy in the Arctic], Keji yu Qiye, 10 (2013), pp. 5-6.

HOLTM, P. et al., 2011, China's energy and security relations with Russia, SIPRI Policy Paper, no. 29, Available at: http://books.sipri.org/product_info?c_product_id=431

HEUBERT, R., 2012, Canada and China in the Arctic: a work in Progress, Meridian Newsletter, Spring/Summer, Available at: http://www.polarcom.gc.ca/eng/content/meridian-newsletter-fallwinter-2011springsummer-2012-0\#fn12

JAKOBSON, L., 2010, China prepares for an Ice free Arctic. SIPRI report No. 2010/2

KUANG, Z., 2011, 俄罗斯的外大陆架政策评析 [An evaluation of Russia's outer continental shelf policy], Erluosi Zhongya Dongou Yanjiu, 2(2011), p. 78.

LANTEIGNE, M., 2013, Chinese Foreign Policy. An introduction. London: Routledge.

LANTEIGNE, M., 2014, China's emerging Arctic strategies: Economics and Institutions. Occasional Papers, Centre for Arctic Policy Studies, Institute of International Affairs. University of Iceland.

LAJEUNESS, A., and LACKENBAUER, P.W., Chinese mining interests and the Arctic, Available at: http://www4.fsa.ulaval.ca/files/content/sites/fsa/files/sections/La recherche/chaires recherche/Stephen-A.JARISLOWSKY/ActesHEI/papers/Chinese\%20mining\%20interests\%20and\%20the\%20artic\%20\%28A.\%20Lai eunesse, \%20P.\%20Whitney\%20Lackenbauer\%29.pdf

LI, Y., 2014, 美国北极战略的新动向及其影响 [New developments in US Arctic Strategy and its implications], Taipingyang Xuebao, no. 6 (2014), p. 48.

LI, X., and BERTELSEN, R.G., 2013, The drivers of Chinese Arctic interests: political stability and energy and transportation security, Arctic Yearbook 2013, Available at: http://www.arcticyearbook.com/images/Articles_2013/LIBERTLESON_AY13_FINAL.pdf?.

LIU, G., 2011, Politics and Government in China. Santa Barbara: ABC-CLIO.

MINISTRY OF COMMERCE, PRC, 2013, Country Report 2013, Available at: http://countryreport.mofcom.gov.cn/record/view110209.asp?news_id=38424

MYERS, S.L., 2013, Arctic Council Adds 6 Nations as Observer States, Including China. New York Times May 15. Available at: http://www.nytimes.com/2013/05/16/world/europe/arctic-council-adds-six- membersincluding-china.html

NRK, 2014, Norsk nei til Kina-radar på Svalbard [Norwagian no to Chinese radar at Svalbard]. Available at: http://www.nrk.no/troms/nekter-kina-radar-pa-svalbard-1.11927625 
PENG, J., and WEGGE, N., 2014, China and the Law of the Sea: Implications for Arctic Governance" The Polar Journal. 4(2): 287-305.

PU, J., 2013, China's Arctic mining adventure left out in the cold, Caixin, 26 Nov. 2013, Available at: http://english.caixin.com/2013-11-26/100609820.html

RAINWATER, S., 2013, Race to the North: China's Arctic strategy and its implications', Naval War College Review, 66 (2), p. 72.

SHAMBAUGH, D., 2013, China goes global. The partial power. Oxford: Oxford University Press.

ROBINSON, R., 2013, China's 'Long Con' in the Arctic, True North in Canadian Public Policy, Commentary, Macdonald-Laurier Institute Publication, Available at:

http://www.macdonaldlaurier.ca/files/pdf/MLIChina'sLongConInTheArctic09-13Draft4-1.pdf.

REUTERS, 2014, Russia's Putin Wants Beefed-up Presence in Arctic, Reuters, 22 Apr. 2014, Available at: http://www.reuters.com/article/2014/04/22/us-russia-putin-arcticidUSBREA3L1BN20140422.

SUN, K., and WANG, C., 2014, 国际利益视角下的中俄北极合作 [Sino-Russian cooperation in the context of global interests], Dongbeiya Luntan, 2014(6), pp. 26-34.

SUTTER, R.G., 2012, Chinese Foreign Relations. Power and Policy since the Cold War. Lanham: Rowman and Littlefield Publishers, Inc.

SUTTER, R.G., 2013, Foreign Relations of the PRC. The Legacies and constraints of China's International Politics since 1949: Lanham: Rowman and Littlefield Publishers, Inc.

STAALESEN, A., 2013, First container ship on Northern Sea Route', 21 Aug. 2013, Available at: http://barentsobserver.com/en/arctic/2013/08/first-container-ship-northern-sea-route-21-08

TAYLOR, I., 2007, Unpacking China's Resource Diplomacy in Africa. Center on China's Transnational Relations. Working Paper No. 19.

THE GLOBE AND MAIL, 2015, Chinese Scientists Look to Canadian Arctic for Research Outpost, Available at: http://www.theglobeandmail.com/report-on-business/industry-news/energy-and-resources/chinese-scientistsdream-of-arctic-research-outpost-in-the-north/article23527009/

THE STAR, 2012, Harper in China: free trade agreement with China in Canada's sights?', Available at: http://www.thestar.com/news/canada/2012/02/11/harper_in_china free trade_agreement_with_china_in_canada $\underline{\text { s_sights.html }}$

US DEPARTMENT OF STATE, 12 July 2013, U.S.-China Strategic and Economic Dialogue Outcomes of the Strategic Track', Available at: http://www.state.gov/r/pa/prs/ps/2013/07/211861.htm.

VOICE OF RUSSIA, 2014, 中国公司落地俄罗斯北极 [Chinese Firms Landed on Russia’s Arctic], Available at: http://radiovr.com.cn/2014_01_15/259380420/

VG, 2014, Slutt på hemmelige knefall for Kina.[End of secret bowing to China] 03.September. Available at: http://www.vg.no/nyheter/meninger/kina/slutt-paa-hemmelige-knefall-for-kina/a/23287672/

WHITE, B. 2001, Diplomacy, In BAYLIS, J. and STEVE S.,(eds.): The Globalization of world politics. Oxford: Oxford University Press.

WHITE HOUSE, 2015, Executive Order --- Enhancing Coordination of National Efforts in the Arctic. The White House. Office of the Press Secretary. January 21.

WHITE HOUSE, 2013, National Strategy for the Arctic Region, Available at: https://www.whitehouse.gov/sites/default/files/docs/nat_arctic_strategy.pdf

WANG, Z., 2013, Not Rising, But Rejuvenating: The “Chinese Dream”. The Diplomat February 05.

WEGGE, N., 2014, China in the Arctic. Interests, actions and challenges. Nordlit 32: 83-98.

WRIGHT, T.C., 2013, China's new Arctic stratagem: a strategic buyer's approach to the Arctic, Journal of Military and Strategic Studies, 15(1), p. 29.

WU, B., RENHE Z., ROSANNE D. and JINGZHI SU, 2013, On the Relationship between Winter Sea Ice and Summer Atmospheric Circulation over Eurasia”. Journal of Climate, 26: 5523-5536.

ZHENMIN, L. 2011, Speech of Assistant Minister of Foreign Affairs, at the 2011 High North study tour, Available at: 
http://webcache.googleusercontent.com/search?q=cache:k6eaD0e9xv0J:www.fmprc.gov.cn/eng/wjb/zzjg/tyfls/tf $\underline{\text { sxw/t812046.shtml }+\& c d=1 \& h l=e n \& c t=c l n k \& g l=j p}$

ZHANG, X. et al., 2014, 从破冰船强制领航到许可证制度一俄罗斯北方航道法律新变化分析 [An analysis of Russia's changing Northern Sea Route regulations-from obligatory navigation assistance to permit system], Jidi Yanjiu, 26 (2), p.274.

ZHU, Z., 2013, China's New Diplomacy. Rationale, Strategies and Significance. Farnham: Ashgate. 